\title{
Bidirectional recanalization of a complete postradiation stricture of the hypopharynx and esophagus.
}

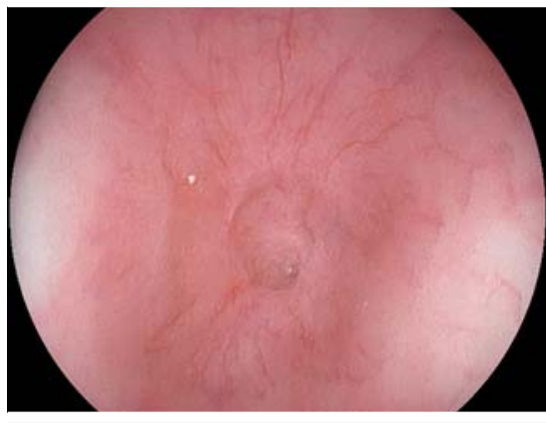

- Fig. 1 Retrograde view of the atretic stricture.

A 65-year-old patient was referred for endoscopic management of a complete radiation-induced stricture, $5 \mathrm{~cm}$ in length, of the hypopharynx and esophagus ( $>$ Fig. 1, > Video 1). He had a history of curative chemoradiation therapy for T2N1 squamous cell carcinoma of the larynx. His nutrition was exclusively maintained through a percutaneous gastrostomy. Recanalization of the esophagus was considered after a multidisciplinary discussion, as previously described [1-3]. The percutaneous gastrostomy site was reinforced by providing endoscopic gastropexy to the abdominal wall with four sutures using a double-needle device (Freka Pexact; Fresenius Kabi Ltd, Runcorn, UK). The gastrostomy site was bougie-dilated to $14 \mathrm{~mm}$ and a 9-mm endoscope was inserted. A mixture of hydroxyethyl starch and indigo carmine was injected and the fibrotic tissue was dissected with a 1.5-mm Dual Knife (Olympus, Tokyo, Japan) (\$ Fig.2). Step by step a new lumen was created up to the level of the hypopharynx. At this level, a perorally introduced gastroscope was able to discern transillumination and an endoscopic rendezvous was achieved ( $>$ Fig. 3 ). At the end of the procedure, the proximal orifice was sufficiently dissected up to $10 \mathrm{~mm}$ ( $\triangleright$ Fig.4, $>$ Fig.5). The patient was admitted for 48 hours for observa-

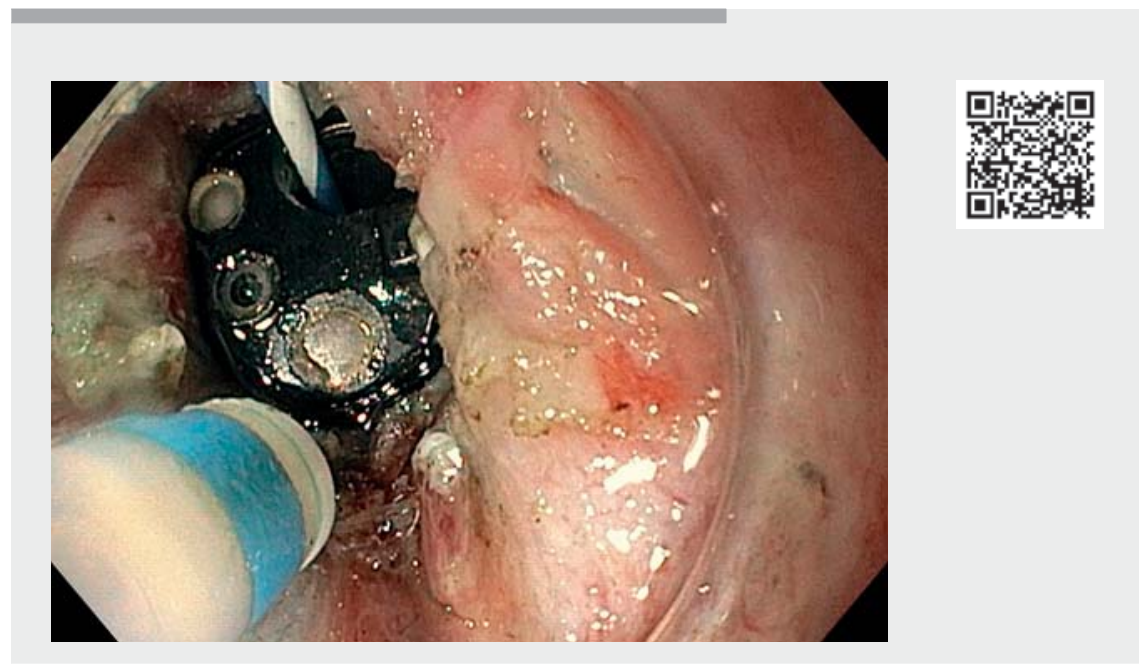

$\checkmark$ Video 1 Video presentation of the endoscopic management of the stricture.

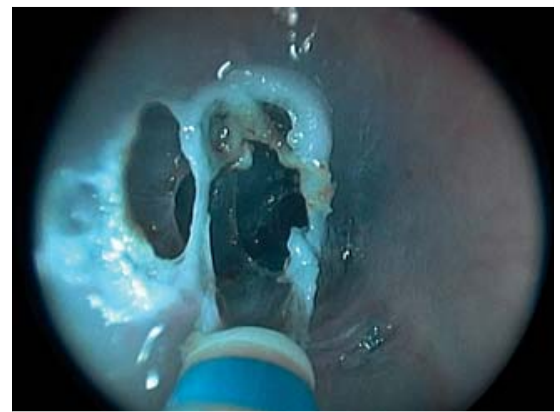

- Fig. 2 Retrograde view. Dissection of the stricture.

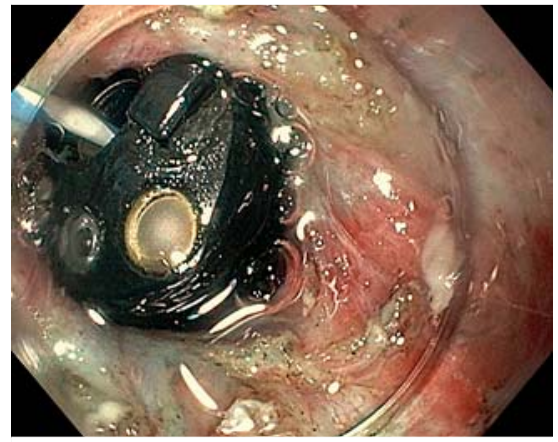

- Fig. 4 Antegrade view. Enlargement of the stricture to fit a standard endoscope.

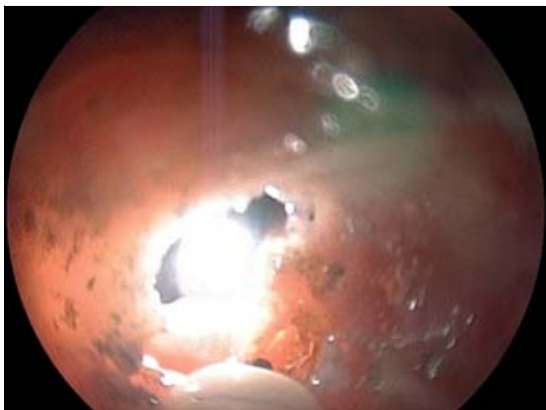

Fig. 3 Retrograde view. Transillumination.

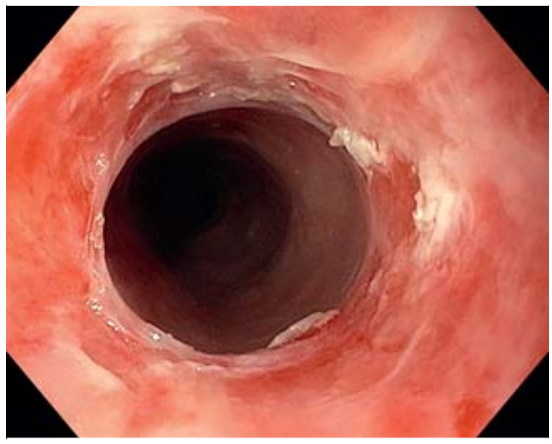

Fig. 5 Inspection of the stricture 3 days later. 
tion and discharged uneventfully. No stent was placed due to the risk of intolerance and/or creation of a fistula [3].

At 5 months of follow-up, the patient underwent serial endoscopic balloon dilations up to $20 \mathrm{~mm}$ to keep the tunneled stricture patent. In conclusion, complete postradiation strictures of the esophagus and hypopharynx could be managed by bidirectional dissection of the fibrotic tissue. Although technically challenging, this procedure may spare the need for more invasive and morbid surgery. The addition of gastropexy prior to the main procedure and the bidirectional approach of recanalization are the two elements that differentiate our approach from previously published case reports.

Endoscopy_UCTN_Code_CCL_1AB_2AC_3AD

\section{Competing interests}

The authors declare that they have no conflict of interest.
The authors

Georgios Mavrogenis ${ }^{1}$, Fateh Bazerbachi², Konstantinos Markoglou ${ }^{1}$, Sandro Porceddu ${ }^{3}$, Sunil Gupta ${ }^{4}$, Luke Hourigan ${ }^{4}$

1 Unit of Hybrid Interventional Endoscopy, Department of Gastroenterology, Mediterraneo Hospital, Athens, Greece

2 Department of Gastroenterology, CentraCare, St. Cloud, Minnesota, USA

3 Department of Oncology, Brisbane's Princess Alexandra Hospital, Brisbane, Australia

4 Department of Gastroenterology, Brisbane's Princess Alexandra Hospital, Brisbane, Australia

\section{Corresponding author}

\section{Georgios Mavrogenis, MD}

Unit of Hybrid Interventional Endoscopy, Department of Gastroenterology, Mediterraneo Hospital, Ilias 12, Glyfada 16675 Athens, Greece mavrogenis@gmail.com

\section{References}

[1] Wagh MS, Yang D, Chavalitdhamrong D et al. Per-oral endoscopic tunneling for restoration of the esophagus (POETRE). Gastrointest Endosc 2014; 80: 330

[2] Mavrogenis G, Moreels TG, Chevaux JB et al. Recanalization of a complete postradiation esophageal obstruction with endoscopic submucosal dissection techniques. Gastrointest Endosc 2015; 81: 1476
[3] Félix C, Barreiro P, Rodrigues Azevedo J et al. Per-oral endoscopic tunneling for restoration of the esophagus (POETRE) in the management of a complete esophageal obstruction. Endosc Int Open 2021; 9: E1084E1085

\section{Bibliography}

Endoscopy 2022; 54: E709-E710

DOI 10.1055/a-1753-9450

ISSN 0013-726X

published online 28.2.2022

(c) 2022. Thieme. All rights reserved.

Georg Thieme Verlag KG, Rüdigerstraße 14,

70469 Stuttgart, Germany

\section{ENDOSCOPY E-VIDEOS}

https://eref.thieme.de/e-videos

口回 Endoscopy E-Videos is an open access online section. 回触: reporting on interesting cases and new techniques in gastroenterological endoscopy. All papers include a high quality video and all contributions are freely accessible online. Processing charges apply (currently EUR 375), discounts and wavers acc. to HINARI are available.

This section has its own submission website at https://mc.manuscriptcentral.com/e-videos 